\title{
Synthesis and screening of anticancer potentials of some new terephthaldehyde-derived nitrone compounds
}

\author{
Husam Hamza Salman ${ }^{1 *}$, Munther Abduljaleel Mohammed Ali ${ }^{1}$, Eman Tariq $\mathrm{Ali}^{2}$ \\ ${ }^{1}$ Department of Pharmaceutical Chemistry, ${ }^{2}$ Department of Laboratories Clinical Science, College of Pharmacy, University of \\ Basrah, Basrah, Iraq
}

${ }^{\star}$ For correspondence: Email: hussam_712003@yahoo.com

Sent for review: 17 June 2019

Revised accepted: 22 January 2020

\begin{abstract}
Purpose: To synthesize and screen some new nitrone compounds derived from terephthaldehyde for their anticancer potential.

Methods: Six new compounds ( $\mathrm{H}, \mathrm{p}-\mathrm{Me}, \mathrm{p}-\mathrm{Br}, \mathrm{p}-\mathrm{Cl}, \mathrm{o}-\mathrm{Cl}$ and $\mathrm{m}-\mathrm{Me}$ ) were synthesized via a condensation reaction between terephthaldehyde and a variety of aryl hydroxylamine compounds derived from nitrobenzene and its derivatives. The chemical structures of these compounds were identified using elemental CHN analysis and were elucidated using Fourier Transform infra-red (FT-IR), ${ }^{1} \mathrm{H}$-nuclear magnetic resonance $\left({ }^{1} \mathrm{H} N \mathrm{NR}\right)$, mass spectrometry $(\mathrm{MS})$, and elemental analysis. The anticancer effects of the compounds were screened in vitro with respect to their cytotoxicity on MCF7 human cancer cells line. The $I C_{50}$ values were obtained by MTT assay and their effects on apoptosis of MCF-7 cells were assessed using Acridine orange-ethidium bromide AO/EtBr staining method under a fluorescence microscope.

Results: Only four compounds (2b, 2d, 2e, and 2f) inhibited more than $50 \%$ of the growth of MCF-7 cells. The strongest anti-proliferation effect against MCF-7 cells was exhibited by $2 \mathrm{f}(\mathrm{m}-\mathrm{Me})$, producing more apoptosis which increased membrane disruption and consistency of lysosome vacuoles; it also exhibited higher cytotoxic effects on human cancer cell lines $\left(I C_{50}<7.5\right)$ than the other synthesized compounds.

Conclusion: The new nitrone compounds $(2 b, 2 d, 2 e$, and 2f) synthesized from terephthaldehyde exhibit some anticancer properties, and so are potential anticancer agents.
\end{abstract}

Keywords: Terephthaldehyde, Nitrone, Cytotoxicity, Anticancer, MCF-7 cells

\begin{abstract}
This is an Open Access article that uses a fund-ing model which does not charge readers or their institutions for access and distributed under the terms of the Creative Commons Attribution License (http://creativecommons.org/licenses/by/4.0) and the Budapest Open Access Initiative (http://www.budapestopenaccessinitiative.org/read), which permit unrestricted use, distribution, and reproduction in any medium, provided the original work is properly credited.
\end{abstract}

Tropical Journal of Pharmaceutical Research is indexed by Science Citation Index (SciSearch), Scopus, International Pharmaceutical Abstract, Chemical Abstracts, Embase, Index Copernicus, EBSCO, African Index Medicus, JournalSeek, Journal Citation Reports/Science Edition, Directory of Open Access Journals (DOAJ), African Journal Online, Bioline International, Open-J-Gate and Pharmacy Abstracts

\section{INTRODUCTION}

Nitrones are 1,3-dipolar compounds which contain the azomethine group $\left(-\mathrm{C}=\mathrm{N}^{+}-\mathrm{O}^{-}\right)$[1] and exert biological and chemical effects. In addition, the azomethine group possesses an oxygen atom bonded to the nitrogen atom $(-\mathrm{CH}=\mathrm{NO}-)$ by co-ordinate bond
[2]. These compounds possess numerous beneficial and pharmacological effects such as anticancer [3], antifungal [4], neuroprotective [5], antibacterial [6] and antioxidant [4] properties. The most effective method used in the synthesis of nitrones involves a condensation reaction between hydroxylamines and carbonyl 
compounds. This reaction smoothly proceeds with high yield $[7,8]$.

Cancer is an ailment where numerous anomalous cells grow wildly, paying little mind to the customary standards of cell division [9]. Cancer ranks second after heart disease among diseases that result in the high death rate of patients, Cancer represents about $23 \%$ of all demise cases in the united kingdom with breast cancer MCF-7 being the most wide-spread [10]. The exact cause of cancer has not yet been determined, in spite of the fact that the hereditary viewpoint is engaged with 5 to $10 \%$ of cancer [11]. Different causes incorporate diseases, unhealthiness, weight, absence of physical movement, contamination and tobacco use. These variables influence the movement of biogenes legitimately or by implication that can prompt cancer [11]. The target of the present examination was to investigate the potential anticancer impacts of some new nitrones derived from terephthaldehyde against the MCF-7 cell line.

\section{EXPERIMENTAL}

\section{Materials}

Terephthaldhyde, absolute ethanol, mnitrotoluene, $\quad p$-nitrotoluene, $\quad 0$ chloronitrobenzene, $p$-bromonitrobenzene and $p$ chloronitrobenzene were obtained from SigmaAldrich Company. Nitrobenzene, ammonium chloride and zinc dust were obtained from BDH Company.

\section{Instruments}

The melting points of the synthesized nitrone compounds were determined on the Gallenkimp apparatus, while $\mathrm{CHN}$ analysis was carried out on UoroVector model/EA3000A. The FT-IR 8400 S SHIMADZU apparatus was used to record the IR spectra using $\mathrm{KBr}$ disks. Bruker model ultra-shield $500 \mathrm{MHz}$ (Switzerland) was used to obtain ${ }^{1} \mathrm{H}-\mathrm{NMR}$ spectra at Tehran University, Iran. Deuterated dimethyl sulfoxide used as a solvent, with TMS (tetra-methyl silane) as the internal standard.

\section{Synthesis of $\mathrm{N}$-substitutedphenylhydroxyl- amine (1a, 1b, and 1f)}

In a $500-\mathrm{mL}$ conical flask, a mixture of the corresponding nitrobenzene (0.205 moles), $\mathrm{NH}_{4} \mathrm{Cl}(0.235$ moles$)$ and water $(400 \mathrm{ml})$ was stirred vigorously. Zinc dust powder $(31 \mathrm{~g})$ was added portion-wise for $20 \mathrm{~min}$. The stirring continued for $20 \mathrm{~min}$. The mixture was filtered off then washed with hot water. Thereafter, to saturate the filtrate, $\mathrm{NaCl}$ was added. Then by using an ice-bath for cooling the reaction mixture. The resultant hydroxylamine was filtered and recrystallized from toluene and petroleum ether [12].

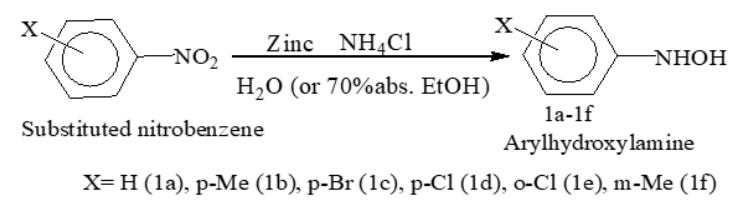

\section{Synthesis of $\mathrm{N}$-substitutedphenylhydroxyl-} amine (1c and 1d)

The above method was modified using $70 \%$ ethanol. In $200 \mathrm{ml}$ of $70 \%$ ethanol, $\mathrm{NH}_{4} \mathrm{Cl}(0.115$ moles) and the appropriate halonitrobenzene (0.1 mole) was dissolved. The mixture was stirred with heating at $60{ }^{\circ} \mathrm{C}$ for $45 \mathrm{~min}$. Thereafter, the mixture was saturated with $\mathrm{NaCl}$ then purified while hot. Desired hydroxylamine was filtered and recrystallized from toluene and petroleum ether[12].

\section{Synthesis of nitrones (2a-2d and 2f)}

A mixture of terephthaldehyde (0.02 moles) and arylhydroxylamine i.e. 1a-1d and $\mathbf{1 f}$ (0.081 moles) in $20 \mathrm{ml}$ of absolute $\mathrm{EtOH}$ was stirred overnight. The desired nitrone was filtered and purified from ethanol[13]. The procedures used for the synthesis of nitrones are summarized in Table 1.

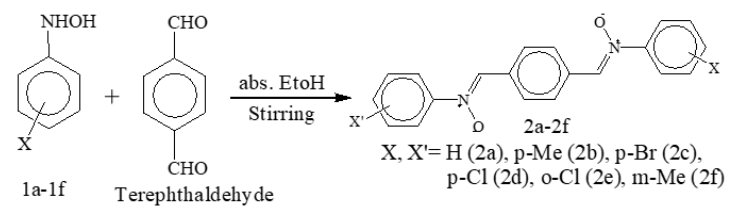

\section{Synthesis of nitrone (2e)}

To avoid decomposition of $\mathrm{N}$-(o-chlorophenyl) hydroxylamine, the previous procedure was modified as follows: A mixture of $\mathrm{O}^{-}$ chloronitrobenzene (0.036 moles) and ammonium chloride $(0.046$ moles) in $25 \mathrm{ml}$ of 60 $\%$ ethanol was stirred at $10^{\circ} \mathrm{C}$. While stirring at $10^{\circ} \mathrm{C}, 0.065 \mathrm{~mol}$ of zinc dust was added portionwise over a period of $1 \mathrm{~h}$. The precipitate formed was filtered and washed three times with $8 \mathrm{ml}$ of boiling ethanol, and 0.018 moles of terephthaldehyde were added to the alcoholic filtrate. At room temperature, the mixture was stirred for 20 hour, next the precipitated nitrone was filtered and recrystallized from absolute ethanol. 


\section{Reagents and chemicals}

The breast cancer cell line (MCF-7) was gotten from the Iraqi Center of Cancer and Medical Genetics Research (ICCMGR). RPMI-1640 medium was purchased from Gibco (USA). Sodium salicylate was purchased from Fluka Company (Switzerland), while Phosphate buffer saline was provided by OXOID (England). Furthermore, crystal violet stain, 3-(4,5-Dimethyl2-thiazolyl)-2,5-diphenyl-2H-tetrazolium bromide (MTT).

Acridine orange (AO), fetal bovine serum, trypsin-EDTA, ethidium bromide (EB) and dimethyl sulfoxide (DMSO) were given from Sigma-Aldrich (St Louis, MO, USA). Kapa Biosystems, Inc. BioSource International (Belgium) provided a penicillin-streptomycin solution. All chemicals applied were of the diagnostic evaluation in this examination. All solutions and buffers were set up as substantive previously[14].

\section{Determination of anticancer activity}

\section{Cell viability}

The effects of the six chemical compounds $(\mathrm{H}, \mathrm{p}$ $\mathrm{Me}, \mathrm{p}-\mathrm{Br}, \mathrm{p}-\mathrm{Cl}, \mathrm{o}-\mathrm{Cl}$, and $\mathrm{m}-\mathrm{Me}$ ) on the viability of MCF-7 cell line were evaluated using SUNRICE Tecan absorbance reader (Schooler) for measuring the absorbance at $620 \mathrm{~nm}$. The growth medium was decanted and the cell culture was washed once with $2 \mathrm{ml}$ trypsinversene solution.

Approximately 2-3 $\mathrm{ml}$ of trypsin-Bersin was added to the cell culture, then culture flask was rocked gently, then the culture was incubated at $37^{\circ} \mathrm{C}$ until the cells separated from the flask. The cells were dispensed in a $5 \mathrm{ml}$ growth medium and redistributed at the required density into the culture. The cells were brooded in a humidified climate containing $5 \% \mathrm{CO}_{2}$ at $37{ }^{\circ} \mathrm{C}$ [14].

\section{MTT assay}

This examine was finished by a prior qualified technique [15]. The cells were seeded in 96-well microtiter plates with RPMI medium at a concentration of $1 \times 10^{5}$ cells $/ \mathrm{ml}$, then were incubated overnight for attachment. At that point, $(100 \mu \mathrm{g} / \mathrm{mL})$ from each compound were added in triplicate to the wells at various concentrations $(25,50,100,200$, and $300 \mu \mathrm{g} / \mathrm{mL})$, followed by incubation for $72 \mathrm{hr}$. Thereafter, MTT was added to the cells at a concentration of $2 \mu \mathrm{g} / \mathrm{mL}$, followed by further incubation for $3 \mathrm{hr}$. Next the incubation time, the MTT was aspirated from the wells then supplanted with DMSO to break up the formazan crystals formed. The cells were additionally incubated for $15 \mathrm{~min}$ before deciding the absorbance of each well at $620 \mathrm{~nm}$. The percentage of cytotoxicity was determined using Eq 1.

$H(\%)=\{(A-B) / A\} 100 \ldots \ldots \ldots(1)$

where $\boldsymbol{A}$ and $\boldsymbol{B}$ are the absorbance of the control, and test samples, respectively.

\section{Acridine orange-ethidium bromide $(\mathrm{AO} / \mathrm{EtBr})$ double recolouring}

The capability of the compounds to stimulate the death of the MCF-7 cells was tried utilizing the $\mathrm{AO} / \mathrm{EtBr}$ recolouring method [16]. The cells were seeded into 96-well microtiter plates in RPMI medium at a concentration of $1 \times 10^{5}$ cells $/ \mathrm{ml}$ and were incubated overnight for attachment. Then, the cells were incubated by $(100 \mu \mathrm{g} / \mathrm{mL})$ with each of ( $p-\mathrm{Me}, \mathrm{p}-\mathrm{Cl}, \mathrm{o}-\mathrm{Cl}$ and $\mathrm{m}-\mathrm{Me}$ ) for $24 \mathrm{~h}$, followed by washing using PBS. Thereafter, 100 $\mu \mathrm{L}$ of dual fluorescent dye was added to the wells prior to the visualization of the cells under a fluorescence microscope.

\section{Determination of $\mathrm{IC}_{50}$}

The concentration of compounds which produced $50 \%$ inhibition of cell development $\left(\mathrm{IC}_{50}\right)$ was resolved from cell survival (\%) versus drug concentration $(\mu \mathrm{g})$ curves. yielding an equation used to compute the concentration of substance required to produce a half decrease in cell viability $\left(\mathrm{IC}_{50}\right)$ as past outlined $[17,18]$.

\section{Statistical analysis}

Both unpaired $t$-tests with Graph Pad Prism 6 were used statistically analyzed the data obtained. The values are introduced presented as mean \pm standard deviation (SD) of triplicate estimations. Both Bonferroni's post-test and One-way ANOVA were utilized for factual investigation [19]. Analysis of the non-linear regression curve for $\mathrm{IC}_{50}$ determination was done with Graph Pad PRISM version 6 (Graph Pad Software, Inc., La Jolla, CA, USA)

\section{RESULTS}

The results of the mass spectral characterization of the synthesized compounds are listed in Table 1 , along with other physical data. 
Table 1: Physical data of the synthesized nitrones

\begin{tabular}{|c|c|c|c|c|c|}
\hline Compound & $\mathbf{X}, \mathbf{X}^{\prime}$ & Name & Mol. formula & m.p. $\left({ }^{\circ} \mathrm{C}\right)$ & $\begin{array}{l}\text { Yield } \\
(\%)\end{array}$ \\
\hline $2 a$ & $\mathrm{H}$ & $\begin{array}{c}\text { 1,4-phenylene-bis }(N- \\
\text { phenylmethanimine } N \text {-oxide })\end{array}$ & $\mathrm{C}_{20} \mathrm{H}_{16} \mathrm{~N}_{2} \mathrm{O}_{2}$ & $261-263$ & 94 \\
\hline $2 b$ & $\mathrm{p}-\mathrm{Me}$ & $\begin{array}{l}\text { 1,4-phenylene-bis }[\mathrm{N}-(4- \\
\text { methylphenyl)methanimine } \mathrm{N} \text {-oxide] }\end{array}$ & $\mathrm{C}_{22} \mathrm{H}_{20} \mathrm{~N}_{2} \mathrm{O}_{2}$ & $267-268$ & 86 \\
\hline 2c & $\mathrm{p}-\mathrm{Br}$ & $\begin{array}{l}\text { 1,4-phenylene-bis }[\mathrm{N}-(4- \\
\text { bromophenyl)methanimine } \mathrm{N} \text {-oxide] }\end{array}$ & $\mathrm{C}_{20} \mathrm{H}_{14} \mathrm{Br}_{2} \mathrm{~N}_{2} \mathrm{O}_{2}$ & $278-280$ & 75 \\
\hline $2 d$ & $\mathrm{p}-\mathrm{Cl}$ & $\begin{array}{l}\text { 1,4-phenylene-bis[ }[N-(4- \\
\text { chlorophenyl)methanimine } N \text {-oxide] }\end{array}$ & $\mathrm{C}_{20} \mathrm{H}_{14} \mathrm{Cl}_{2} \mathrm{~N}_{2} \mathrm{O}_{2}$ & $251-252$ & 78 \\
\hline $2 e$ & $\mathrm{O}-\mathrm{Cl}$ & $\begin{array}{l}\text { 1,4-phenylene-bis }[N-(2- \\
\text { chlorophenyl)methanimine } N \text {-oxide] }\end{array}$ & $\mathrm{C}_{20} \mathrm{H}_{14} \mathrm{Cl}_{2} \mathrm{~N}_{2} \mathrm{O}_{2}$ & $217-219$ & 68 \\
\hline $2 f$ & m-Me & $\begin{array}{c}\text { 1,4-phenylene-bis }[N \text {-(3- } \\
\text { methylphenyl)methanimine } N \text {-oxide] }\end{array}$ & $\mathrm{C}_{22} \mathrm{H}_{20} \mathrm{~N}_{2} \mathrm{O}_{2}$ & $214-216$ & 89 \\
\hline
\end{tabular}

Table 2 shows the elemental $(\mathrm{CHN})$ data for the synthesized nitrones $(\mathbf{2 a - 2 d})$. The outcome supports the framework of the nitrone compounds.

Table 2: Elemental (CHN) analysis of nitrones (2a-2f)

\begin{tabular}{ccccccc}
\hline Compound & \multicolumn{2}{c}{ Calculated (\%) } & \multicolumn{3}{c}{ Found (\%) } \\
\cline { 2 - 7 } & $\boldsymbol{C}$ & $\boldsymbol{H}$ & $\boldsymbol{N}$ & $\boldsymbol{C}$ & $\boldsymbol{H}$ & $\boldsymbol{N}$ \\
\hline 2a & 75.93 & 5.10 & 8.86 & 77.13 & 5.42 & 8.66 \\
$2 \mathrm{~b}$ & 76.72 & 5.85 & 8.13 & 76.88 & 5.81 & 8.28 \\
$2 \mathrm{c}$ & 50.66 & 2.98 & 5.91 & 50.88 & 3.19 & 5.93 \\
$2 \mathrm{~d}$ & 62.35 & 3.66 & 7.27 & 62.65 & 3.87 & 7.53 \\
$2 \mathrm{e}$ & 62.35 & 3.66 & 7.27 & 62.88 & 4.16 & 7.67 \\
$2 \mathrm{f}$ & 76.72 & 5.85 & 8.13 & 77.20 & 5.52 & 8.01 \\
\hline
\end{tabular}

\section{FT-IR spectra}

The medium absorption band observed at (1673 - $1593 \mathrm{~cm}^{-1}$ ) for all nitrone compounds (Table3) was due to the stretching vibration of the $\mathrm{C}=\mathrm{N}$ group. The FT-IR spectra of nitrones showing a very strong band at regions $1180-1215 \mathrm{~cm}^{-1}$ and $1068-1095 \quad \mathrm{~cm}^{-1}$ can are due to the stretching frequencies of $\mathrm{C}-\mathrm{N}$ and $\mathrm{N}-\mathrm{O}$ bonds, respectively.

Stretching frequencies of the aromatic $\mathrm{C}-\mathrm{H}$ occurred at $3047-3128 \mathrm{~cm}^{-1}$. Out-of-plane bending (o.o.p bend) and in-plane bending (in. pl. bend) of aromatic $\mathrm{C}-\mathrm{H}$ appeared at regions 837 $860 \mathrm{~cm}^{-1}$ and $1393-1420 \mathrm{~cm}^{-1}$, respectively. All infrared spectra of nitrones showed forceful bands at $1454-1481 \mathrm{~cm}^{-1}$ and at $1500-1558$ $\mathrm{cm}^{-1}$ due to the stretching frequencies of the aromatic $\mathrm{C}=\mathrm{C}$ group. Nitrones $\mathbf{2} \mathbf{b}$ and $\mathbf{2 f}$ showed weak bands for aliphatic $\mathrm{C}-\mathrm{H}$ bond at 2920 and $2924 \mathrm{~cm}^{-1}$, respectively $[20,21]$.

\section{${ }^{1} \mathrm{H}-\mathrm{NMR}$ spectra}

The synthesized nitrones exhibited single signals at $8.218-8.621 \mathrm{ppm}$ which are attributable to protons $\mathrm{H}-13$ and $\mathrm{H}-13^{\prime}$. A singlet signal for all spectra of synthesized compounds appeared at 8.481-8.561 ppm, due to the equivalent protons $\mathrm{H}-8, \mathrm{H}-9, \mathrm{H}-11$, and $\mathrm{H}-12$. On the other hand, nitrones $2 \mathbf{a}$ and $2 \mathrm{e}$ exhibited multiple signals at the ranges 7.545-7.952 ppm and 7.515-7.776 ppm, respectively.

In the case of compounds $\mathbf{2} \mathbf{b}$ and $\mathbf{2 f}$, their ${ }^{1} \mathrm{H}$ NMR spectra showed a singlet signal for the methyl group at $2.395 \mathrm{ppm}$ and $2.417 \mathrm{ppm}$, respectively. In the other compounds (2a-2c), the ${ }^{1} \mathrm{H}$-NMR spectra exhibited doublet signals for equivalent protons $\left(\mathrm{H}-3,5\right.$ and $\left.\mathrm{H}-3^{\prime}, 5^{\prime}\right)$ and equivalent protons $\left(\mathrm{H}-2,6 \quad \mathrm{H} 2^{\prime}, 6^{\prime}\right)[20-22]$, as shown in Table 4. The signals of a the ${ }^{1} \mathrm{H}$-NMR spectrum of compound $\mathbf{2 f}$ are summed up in Table 4. 
Table 3: FT-IR $\left(\mathrm{cm}^{-1}\right)$ spectral data for nitrones (2a-2f)

\begin{tabular}{|c|c|c|c|c|c|c|c|c|}
\hline \multirow{2}{*}{ Compound } & \multirow{2}{*}{$\mathrm{C}=\mathrm{N}$} & \multirow{2}{*}{$C=C$} & \multirow{2}{*}{ C-N } & \multirow{2}{*}{$\mathrm{N}-\mathrm{O}$} & \multicolumn{3}{|c|}{ C-H aromatic } & \multirow{2}{*}{$\begin{array}{c}\text { C-H } \\
\text { aliphatic }\end{array}$} \\
\hline & & & & & Str. & o.o.p.bend. & in-pl.. & \\
\hline $2 a$ & 1589 & $\begin{array}{l}1485 \\
1458 \\
1558\end{array}$ & 1192 & 1068 & $\begin{array}{l}3093 \\
3051\end{array}$ & $\begin{array}{l}856 \\
763\end{array}$ & 1404 & - \\
\hline $2 b$ & 1593 & $\begin{array}{l}1454 \\
1500 \\
1554\end{array}$ & 1192 & 1068 & 3053 & $\begin{array}{l}856 \\
767\end{array}$ & 1415 & 2920 \\
\hline $2 c$ & 1581 & $\begin{array}{l}1477 \\
1550\end{array}$ & 1192 & 1072 & 3094 & $\begin{array}{l}837 \\
706\end{array}$ & 1416 & - \\
\hline $2 d$ & 1589 & $\begin{array}{l}1481 \\
1554\end{array}$ & 1180 & 1072 & $\begin{array}{l}3093 \\
3057\end{array}$ & $\begin{array}{l}833 \\
705\end{array}$ & 1420 & - \\
\hline $2 e$ & 1573 & $\begin{array}{l}1496 \\
1469\end{array}$ & 1195 & 1095 & 3047 & $\begin{array}{l}860 \\
756\end{array}$ & 1408 & - \\
\hline $2 f$ & 1585 & $\begin{array}{l}1481 \\
1462 \\
1554\end{array}$ & 1215 & 1068 & $\begin{array}{l}3128 \\
3074\end{array}$ & $\begin{array}{l}845 \\
779\end{array}$ & 1393 & 2924 \\
\hline
\end{tabular}

Str: stretching, O.O.P: Out of plane, in -pl. bend: in-plane bending

Table 4: ${ }^{1} \mathrm{H}-\mathrm{NMR}$ spectra data for compounds $\mathbf{2 a - 2 f}$

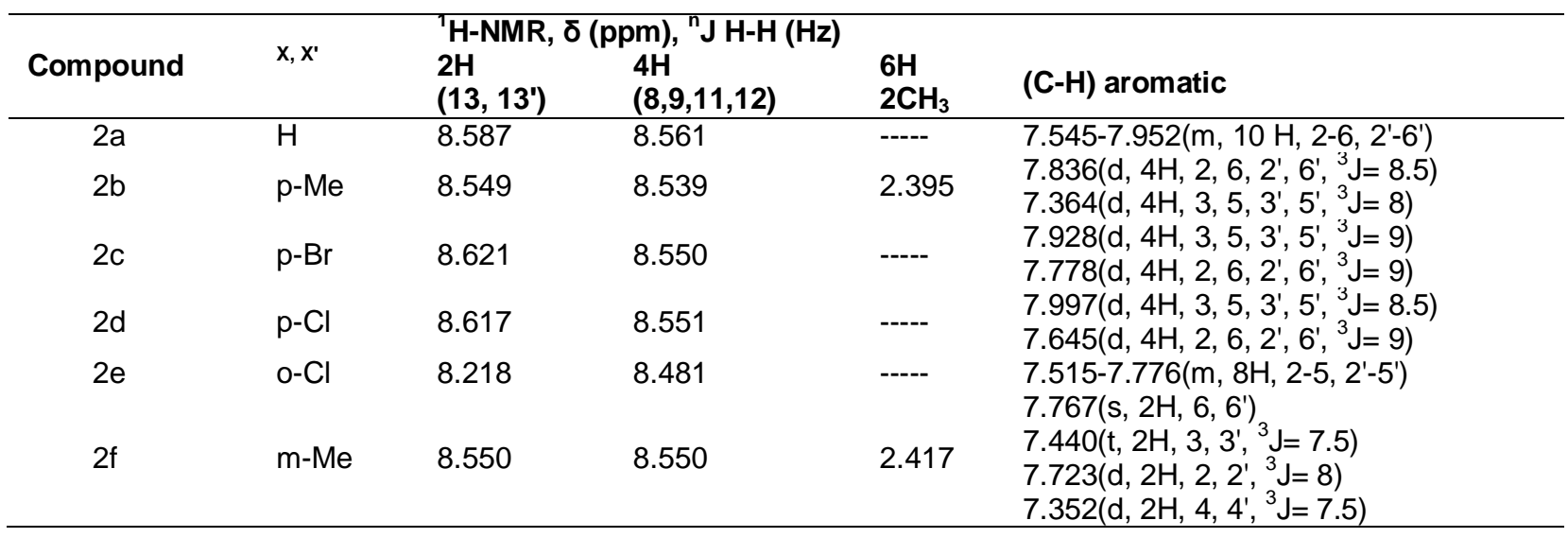

\section{Effect of 2a-2f on cell viability of (MCF-7) cell} line

At first, the cytotoxic effects of the six compounds $(\mathrm{H}, \mathrm{p}-\mathrm{Me}, \mathrm{p}-\mathrm{Br}, \mathrm{p}-\mathrm{Cl}, \mathrm{o}-\mathrm{Cl}$ and $\mathrm{m}-\mathrm{Me}$ ) on the viability of the (MCF-7) cell line for $72 \mathrm{~h}$ was investigated. The outcome appeared significant suppression of cell propagation after $72 \mathrm{~h}$, there was a decrease in cytotoxicity on MCF-7 cell line when handling $2 \mathrm{e}(\mathrm{o}-\mathrm{Cl})$ at a concentration of $100 \mu \mathrm{g} / \mathrm{mL}$, while the cells treated with both bands exhibited moderate cytotoxic impact on the cells at the same concentration. Nitrone 2f, at the grouping of 100 $\mu \mathrm{g} / \mathrm{mL}$ killed $>57.53 \%$ of the cells.

Conversely, neither compound 2a nor compound 2c was able to induce inhibition of cell growth in MCF-7 cell line after $72 \mathrm{~h}$ at the concentration of $100 \mu \mathrm{g} / \mathrm{ml}$ used in the assay (Figure 1). Consequently, these compounds were not used in subsequent studies.

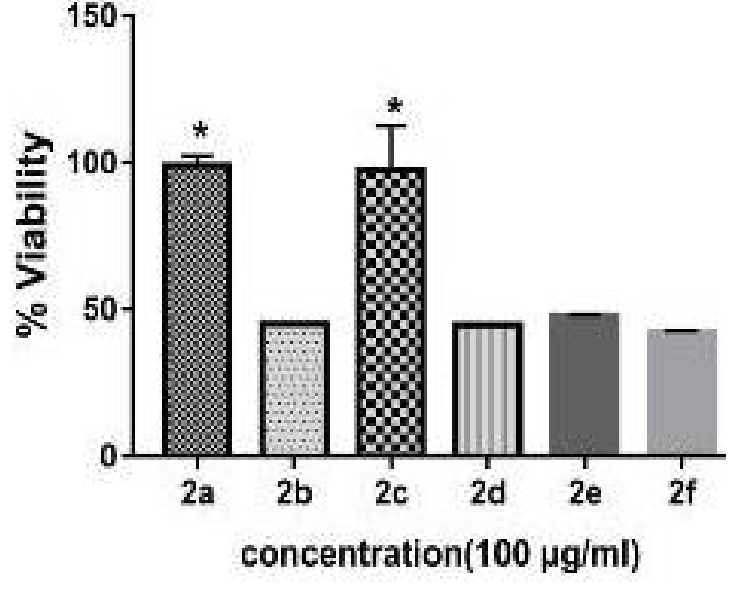

Figure 1: Effect of compounds 2a-2f on cell viability of MCF-7 cells. $2 b$ : cells treated with $p$ $\mathrm{Mel}$; 2d: treated with $\mathrm{p}-\mathrm{Cl}$; $2 \mathrm{e}$ : treated with o-Cl, and 2f: cells treated with m-Me. Each nitrone was used at a concentration of $100 \mu \mathrm{g} / \mathrm{ml} ;{ }^{*} p<$ 0.0001 (one-way ANOVA and Bonferroni's posttest) 
Cytotoxic effect of the compounds on MCF-7 cells

The cytotoxic impacts of $\mathrm{p}-\mathrm{Me}, \mathrm{p}-\mathrm{Cl}, \mathrm{o}-\mathrm{Cl}$ and $\mathrm{m}$ Me on the feasibility of (MCF-7) cell line were studied for $72 \mathrm{~h}$. Only 4 of these compounds were able to inhibit more than $50 \%$ of the growth of MCF-7 cells. Two compounds ( $2 \mathbf{b}$ and $\mathbf{2 f}$ ) exhibited high anti-proliferative effects on cells. The $\mathrm{IC}_{50}$ values for were $7.298 \mu \mathrm{g}$ for $\mathbf{2 b}(\mathrm{p}-\mathrm{Me})$, $8.960 \mu \mathrm{g}$ for $2 \mathrm{~d}(\mathrm{o}-\mathrm{Cl})$, and 10.74 and $7.5 \mu \mathrm{g}$, respectively for $\mathbf{2 e}$ and $\mathbf{2 f}$. The strongest antiproliferation effects on MCF-7 cells lines were produced by $\mathbf{2 b}$ and $\mathbf{2 f}\left(\mathrm{IC}_{50}\right.$ of 7.298 and $7.5 \mu \mathrm{g}$, respectively). A table 4 showing the above results.
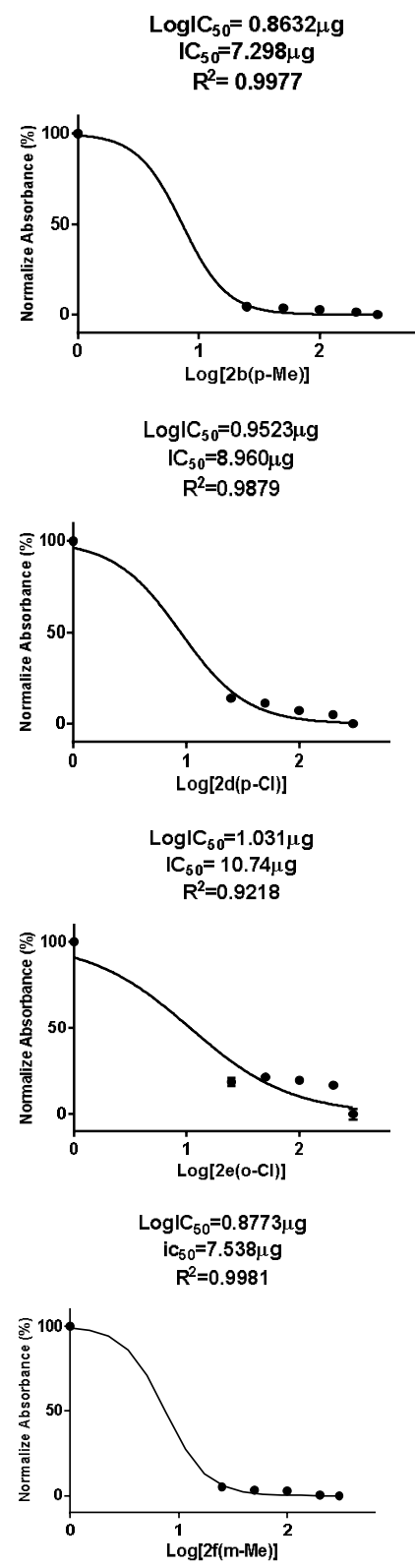

Figure 2: $I C_{50}$ values of compounds $2 b, 2 d, 2 e$, and $2 f$, as obtained from MTT assay. The curves were used for determinations of $\mathrm{IC}_{50}$ values which depicted the cytotoxic effects of the compounds. Each data point is the mean of triplicate determinations.

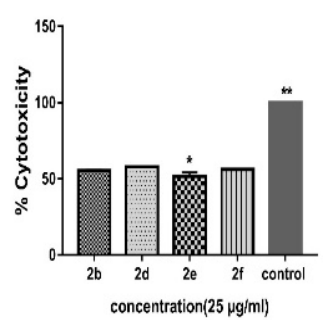

$\mathbf{A}$
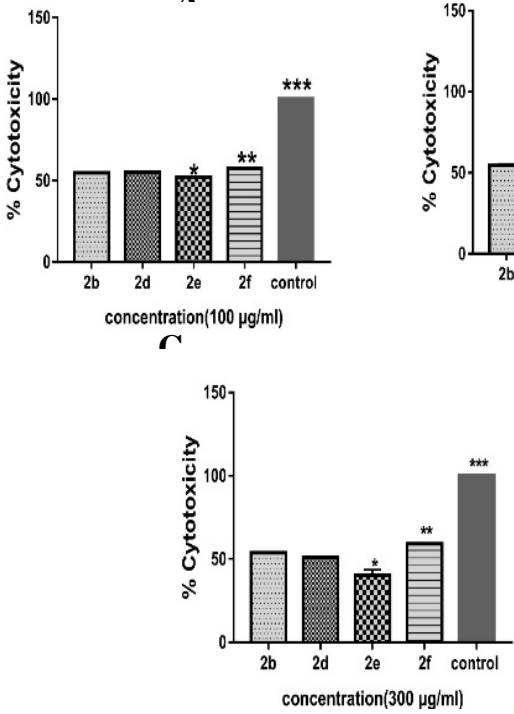

$\mathbf{E}$

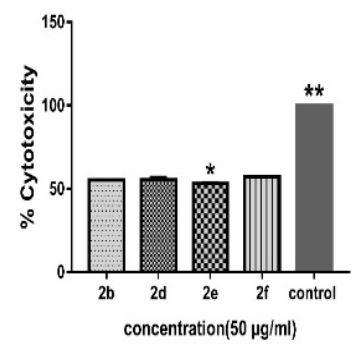

$\mathbf{R}$

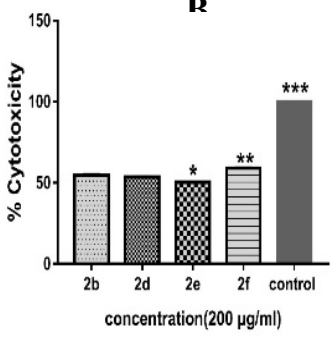

$\mathbf{n}$
Figure 3: Comparison of degrees of inhibition of MCF7 cells amongst the various nitrones at different concentrations (25, 50, 100, 200 and $300 \mu \mathrm{g} / \mathrm{mL})$. (2b) cells treated with $\mathrm{p}-\mathrm{Mel},(\mathbf{2 d})$ cells treated with $\mathrm{p}-\mathrm{Cl}$, (2e) cells treated with $0-\mathrm{Cl}$, and (2f) cells treated with $\mathrm{m}-\mathrm{Me}$ at different concentrations. Each data point represents mean $\pm \mathrm{SD} ;{ }^{*} p<0.01$ (one-way ANOVA and Bonferroni's post-test)

The results in Figure 5, Table 5 were revealed that the ability of these compounds to inhibit MCF-7 proliferation was more than $50 \%$ at all concentrations tested. Bar chart E shows that the compound $2 \mathrm{f}$ had the highest inhibition (59.27\%) at $(300 \mu \mathrm{g} / \mathrm{ml})$ concentration when compared to the other compounds and MCF-7 untreated cells $(p<0.0001)$.

\section{Morphological changes in MCF-7 cell nucleus}

$\mathrm{AO} / \mathrm{EtBr}$ recolouring technique was utilized to study the changes in MCF-7 nuclear morphology after treatment with the different compounds $(2 \mathbf{b}$, $\mathbf{2 d}, \mathbf{2 e}$ and $\mathbf{2 f}$ ). This method is applied to recolour explicit pieces of the cell and to decide the particular apoptotic markers of atomic alterations. 
Table 5: Comparison of compounds in the degree of inhibition of MCF-7cell growth

\begin{tabular}{|c|c|c|c|c|c|c|c|c|c|c|c|}
\hline \multirow{2}{*}{$\begin{array}{c}\text { Conc. } \\
(\mu \mathrm{g} / \mathrm{ml})\end{array}$} & \multicolumn{5}{|c|}{ Nitron compound } & \multirow{2}{*}{$P \leq$} & \multirow{2}{*}{$\begin{array}{c}2 b \\
v s 2 d\end{array}$} & \multirow{2}{*}{$2 b$ vs $2 e$} & \multirow{2}{*}{$2 b$ vs $2 f$} & \multirow{2}{*}{$\begin{array}{c}2 \mathrm{~d} v s \\
2 \mathrm{e}\end{array}$} & \multirow{2}{*}{$2 e$ vs $2 f$} \\
\hline & $2 b$ & $2 d$ & $2 e$ & $2 f$ & Control & & & & & & \\
\hline 25 & 55.57 & 57.93 & 51.52 & 56.17 & 100 & 0.0001 & Ns & 0.01 & Ns & 0.0005 & 0.005 \\
\hline 50 & 55.23 & 55.52 & 53.17 & 57.17 & 100 & 0.0001 & Ns & 0.04 & Ns & 0.02 & 0.0006 \\
\hline 100 & 54.77 & 55.17 & 52.13 & 57.53 & 100 & 0.0001 & Ns & 0.0001 & 0.0001 & 0.0001 & 0.0001 \\
\hline 200 & 54.47 & 53.45 & 50.27 & 58.93 & 100 & 0.0001 & Ns & 0.0001 & 0.0001 & 0.0001 & 0.0001 \\
\hline 300 & 53.7 & 51.03 & 40.4 & 59.27 & 100 & 0.0001 & Ns & 0.0001 & 0.004 & 0.0001 & 0.0001 \\
\hline
\end{tabular}

As shown in Figures (6), all of the nitrones compounds, caused cell death but the $2 \mathrm{f}$ (m-Me) compound produces the most apoptosis when exposure of MCF-7 cells to the compounds led to increased membrane disruption and the formation of lysosome vacuoles, as As shown in (Figure 4) when compared to untreated control cells $(A, B, C$, and $D)$.

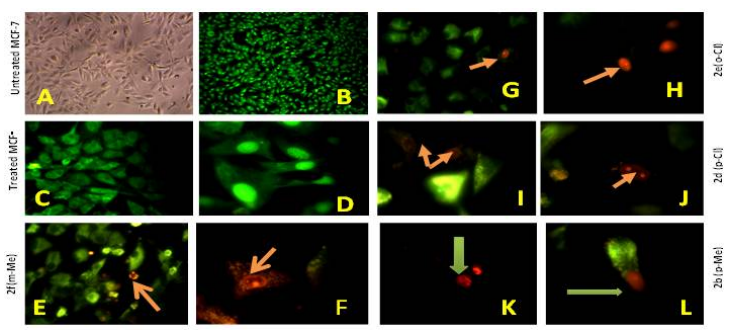

Figure 4: A comparison of the level of apoptosis following treatment with the different compounds. This figure explains the impact of nitrone compounds on apoptosis of MCF-7 cell line by using fluorescence microscop after $24 \mathrm{~h}$ of treatment compared to untreatedMCF-7 cells. $2 f$ was the most compound produced more apoptosis. (A) 10x fluorescence image of untreated, unstained control; (B) x10, (C) x40 and (D) $x 100$ fluorescence images of untreated control stained with $\mathrm{AO} / \mathrm{EtBr}$. (E) $\times 40$ image showing apoptotic cells recolored orange, while the nonapoptotic and viable cells were stained green (arrowed). (F) x100 fluorescence image of MC7 cells treated with $2 f$ compound, showing stain in certain parts of the cell indicating special apoptotic signs of nuclear alterations. (G) $\times 40$ and $(\mathrm{H}) \times 100$ showing stain in specific parts of the cell after treated with $2 \mathrm{e}$ (o-Cl) compound. Also (I) $\times 40$ and (J) $\times 100$ when treated with $2 \mathrm{~d}(\mathrm{p}-\mathrm{Cl})$ compound showing stain in specific parts of the cell. Moreover (K) x40, (L) x100 image indicating special apoptotic signs of nuclear alterations when treated with $2 \mathrm{~b}(\mathrm{p}-\mathrm{Me})$ compound

\section{DISCUSSION}

Generally, the outcome exhibit differences in anti-proliferative, apoptosis and cytotoxic effects amongst the tested compounds. The present study confirmed through the results that these nitrone compounds synthesized from terephthaldehyde (2b, 2d, 2e, and 2f) are effective and have the capability for inhibiting the growth of breast cancer MCF-7 cell by $50 \%$, but there was variance in the degree of inhibition.
More interesting, the study confirmed that nitrone compounds synthesized are new of their kind and there are no previous studies to indicate and support our results. It was found that the potency of cell growth inhibition correlated with the position of the electron-withdrawing nitro group on the tested compounds.

Figures 2 shows that all of the nitrone compounds caused cell death. These results proved that the compounds $\mathbf{2} \mathbf{b}, \mathbf{2 d}, \mathbf{2 e}$ and $\mathbf{2 f}$ are potential sources of efficacious and cytotoxic materials. In any case, the $2 f$ nitrone compounds were discovered the best exacerbates that delivered more apoptosis when contrasted with the other. This compound showed high cytotoxicity through restraint of MCF-7 multiplication, relative to different mixes and untreated MCF-7 cells. Furthermore, the study assumed the effects of $\mathbf{2} \mathbf{f}$ and $\mathbf{2} \mathbf{b}$ might be due to the existence of the methyl group at 4-and 3positions, which may increase their lipophilicity. This is most likely because of the presence of the azomethine group $(-\mathrm{CH}=\mathrm{N}-)$ which possesses biological and chemical properties. Moreover, the azomethine group possesses an oxygen atom bonded. to the nitrogen atom (-CH=NO-) by coordinate bond [2].

These chemical groups are important due to their anticancer effects. Through the results, it turns out that the most significant inhibition at 300 $\mu \mathrm{g} / \mathrm{ml}$ produced by $2 \mathrm{f}$ compound, showing stain in certain parts of the cell indicating specials apoptotic signs of nuclear alterations. The study assumed the mechanism action of this compound when the introduction of compounds to the cells prompted expanded layer disturbance and the development of lysosome vacuoles when contrasted with untreated control cells (Figure 5). This might be because of their capacity to enter the cell layer and influence capability to penetrate the cell membrane and affect the RNA levels of p53, Bax, bcl-2, caspase-3, and caspase-9 $[23,24]$.

\section{CONCLUSION}

The new nitrones compounds $(\mathbf{2} \mathbf{b}, \mathbf{2} \mathbf{d}, \mathbf{2} \mathbf{e}$, and 2f) synthesized from terephthaldehyde exhibit 
some anticancer properties, and so are potential anticancer agents. The strongest antiproliferation effect against MCF-7 cells was exhibited by $2 f(\mathrm{~m}-\mathrm{Me})$ which produced more apoptosis than the other compounds. Thus, 2 f possesses the potential for further development into an effective anticancer and antioxidant agent.

\section{DECLARATIONS}

\section{Acknowledgement}

The authors are thankful to Dr Ali Abd Al Lateef, Education College, University of Basrah for providing facilities to carry out the biological studies.

\section{Conflict of interest}

The authors declare that no conflict of interest is associated with this work.

\section{Contribution of authors}

We declare that this work was done by the authors named in this article and all liabilities pertaining to claims relating to the content of this article will be borne by the authors. Husam Hamza was project administrator. Husam Hamza and Munther Abduljaleel took part in preparation and identification of the nitrone compounds. Husam Hamza and Eman Tariq Ali conceived and designed the study. Husam Hamza and Eman Tariq Ali performed the experimental work. Husam Hamza and Eman Tariq carried out data collation and statistical analyses. Husam Hamza and Eman Tariq prepared the original draft of the manuscript and did review and editing.

\section{Open Access}

This is an Open Access article that uses a funding model which does not charge readers or their institutions for access and distributed under the terms of the Creative Commons Attribution License (http://creativecommons.org/licenses/by/ 4.0) and the Budapest Open Access Initiative (http://www.budapestopenaccessinitiative.org/rea d), which permit unrestricted use, distribution, and reproduction in any medium, provided the original work is properly credited.

\section{REFERENCES}

1. Cheng $Q$, Zhang W, Tagami $Y$, Oritani T. Microwaveinduced 1,3-dipolar intramolecular cycloadditions of $N$ - substituted oximes, nitrones, and azomethine ylides for the chiral synthesis of functionalized nitrogen heterocycles. J Chem Soc, Perkin Transactions 1. 2001; (4): 452-456.

2. Gorichko MV, Domasevitch KV, Petkova EG, Lampeka RD, Zub VY. New Coordination Compounds Derived from Nitrone Ligands: Copper (II) Complexes with 8Hydroxyquinoline-2-carbaldehyde- and Pyridine-2carbaldehyde-N-methylnitrones. Z Naturforsch B 2015; 56(12): 264-1270.

3. A. Floyd R, K. Chandru H, He T, Towner R. Anti-Cancer Activity of Nitrones and Observations on Mechanism of Action. Anti-Cancer Agents Med Chem 2012;1(4): 373379.

4. Ravi Kumar KR, Mallesha H, Rangappa KS. Synthesis of novel isoxazolidine derivatives and their antifungal and antibacterial properties. Arch Pharm 2003; 336(3): 159164.

5. Acharjee N, Banerji A, Banerjee M, Das TK. Indian J of Chem - Section A Inorganic, Physical, Theor and Analyl Chem 2009; 48(12): 1627-1637.

6. Chakraborty $B$, Samanta $A$, Sharma $C D$, Khatun $N$. Synthesis of some novel class of isoxazoline and isoxazolidine derivatives in ionic liquid via 1,3-dipolar cycloaddition reaction of dihydropyran derived nitrones and their antimicrobial activities. Ind $J$ Chem - Section $B$ Organic and Medicinal Chem 2014; 53(2): 218-226.

7. Sadashiva MP, Mallesha $H$, Hitesh NA, Rangappa KS. Synthesis and microbial inhibition study of novel 5imidazolyl substituted isoxazolidines. BioorgMed Chem. 2004; 12(24): 6389-95.

8. Zhang J, Gu X, Chen G, Bai L, Feng L, Ma Y, Yan J, Lin $J$ J. Structure, Anticorrosion and Antibacterial Evaluation of (E)-3-(N-Oxide-methylimino) indolin-2-one. Russ $\mathrm{J}$ of Appl Chem. 2018; 91(5): 750-7.

9. Merrill $S$ a., Mazza A-M. Reaping the Benefits of Genomic and Proteomic Research: Intellectual Property Rights, Innovation and Public Health [Internet]. Natl Acad Sci. 2006. 1-171 p. Available from: http://www.ncbi.nlm.nih.gov/books/NBK19861/

10. Jemal A, Siegel $R$, Ward E, Hao Y. Cancer Statistics, 2008. 2008; 58(2): 71-96.

11. Anand $P$, Kunnumakara $A B$, Sundaram $C$, Harikumar $K B$, Tharakan ST, Lai OS. Expert Review Cancer is a Preventable Disease that Requires Major Lifestyle Changes. 2020; 25(9).

12. Abood ZH. Synthesis of two novel series of azoaldonitrones and preliminary evaluation of their antibacterial activity. 2014;

13. Mobinikhaledi A, Foroughifar N, Kalate Z. Synthesis of some new isoxazolidines by 1,3-dipolar cycloaddition reaction of nitrones and olefins. Turk J Chem. 2005; 29(2):147-52.

14. Borek F. Culture of animal cells: A manual of basic technique. J Immunol Methods. 2003; 183(2): 291.

15. Hayon T, Dvilansky A, Shpilberg O, Nathan I. Appraisal of the MTT-based assay as a useful tool for predicting 
drug chemosensitivity in leukemia. Leuk Lymphoma. 2003; 44(11): 1957-62.

16. Sulaiman GM, Jabir MS, Hameed AH. Nanoscale modification of chrysin for improved of therapeutic efficiency and cytotoxicity. Artif Cells, Nanomed Biotechnol [Internet]. 2018;46(sup1): 708-20. Available from: https://doi.org/10.1080/21691401.2018.1434661

17. Martinho O, Zucca LE, Reis RM. AXL as a modulator of sunitinib response in glioblastoma cell lines. Expl Cell Res [Internet]. 2015; 332(1): 1-10. Available from: http://dx.doi.org/10.1016/j.yexcr.2015.01.009

18. Martinho O, Silva-Oliveira R, Miranda-Gonçalves V, Clara C, Almeida JR, Carvalho AL, et al. In Vitro and In Vivo Analysis of RTK Inhibitor Efficacy and Identification of Its Novel Targets in Glioblastomas. Transl oncol [Internet]. 2013; 6(2): 187-96. Available from: http://www.ncbi.n/m.nih.gov/pubmed/23544171\%0Ahttp: //www.pubmedcentral.nih.gov/articlerender.fcgi?artid=P MC3610556

19. Jabir MS, Sulaiman GM, Taqi ZJ, Li D. Iraqi propolis increases degradation of $I L-1 \beta$ and NLRC4 by autophagy following Pseudomonas aeruginosa infection. MicrobesInfect [Internet]. 2018;20(2):89-100. Available from: $h$ ttps://doi.org/10.1016/j.micinf.2017.10.007
20. Sheela NR, Sampathkrishnan S, Thirumalai Kumar M, Muthu S. Synthesis, spectroscopic (FT-IR, FT-Raman, 13C, $1 \mathrm{H}$, UV) study, first order hyperpolarizability, NBO analysis, HOMO and LUMO analysis of 2(2Hydroxyphenyl)-N-(4-Methylphenyl) Nitrone. Spectrochim Acta - Part A: Mol Biomol Spectrosc [Internet]. 2013; 109: 272-81. Available from: http://dx.doi.org/10.1016/j.saa.2013.03.030

21. Abbas AF, Departement C, Science C. Synthesis, Characterization And Computational Study of Some Diyl ((Bis ( $N$ - (4-Formylbenzylidene) Aniline Oxide) Derivatives. 2017; 7(2).

22. Taqa $A A$. Some complexes of $\mathrm{N}$-aryl furfural nitrones with $\mathrm{Co}$ (II), Ni (II), Cu (II), Zn (II) and Cd (II) chlorides. Int J Adv Chem. 2016; 4(1): 10.

23. Danafar H, Schumacher U. MPEG-PCL copolymeric nanoparticles in drug delivery systems. Cogent Med. 2016; 3(1): 1142411.

24. Alarifi S, Ali H, Alkahtani S, Alessia MS. Regulation of apoptosis through bcl-2/bax proteins expression and DNA damage by nano-sized gadolinium oxide. Int $J$ Nanomedicine. 2017; 12: 4541-4551. 